\title{
FUTURE OF EUROPEAN STANDARDIZATION: EUROPEAN STANDARDS FOR SERVICES
}

\author{
Dr. Fatma Müge ALGAN*
}

\begin{abstract}
Standardization is an important tool for achieving economic growth and competitiveness, increasing employment and development of new sectors. Service sector is an emerging market with its large economic volume. European standards for services have a major importance to improve service sector throughout the Europe and to boost the single market for services. This article introduces benefits of standards for industry, growth and SMEs and introduces standardization work of European Commission and European Standards Organisations on services and offers standardization of public services in the light of Citizen Charters.
\end{abstract}

Keywords: Standardization, Services, Citizen Charters.

JEL Sinıflandırmast: F53, O19.

\section{AVRUPA STANDARDİASYONUN GELECEĞİ: AVRUPA HİZMET STANDARTLARI}

\section{ÖZ}

Standardizasyon ekonomik büyüme, rekabet gücünün artırllması, yeni sektörlerin gelişmesi ve istihdamın artırllmasında önemli bir araçtır. Hizmet sektörü geniş ekonomik hacme ve pazar potansiyeline sahiptir. Avrupa Hizmet Standartları bu sektörün gelişmesi, pazar payının artırllması ve Avrupa Hizmet Tek Pazarının desteklenmesi için büyük öneme sahiptir. Bu çalışma; sanayi, ekonomik büyüme ve KOBI'ler için standardizasyonun getirilerini incelemekte ve hizmetler alaninda Avrupa Komisyonu ve Avrupa Standart Kurumlarının standardizasyon çalışmalarını tanıtmaya çalışmaktadır. Çalışmada Vatandaş Sözleşmeleri örneklemesi ile kamu hizmetlerinin standartlaştırılması önerilmektedir.

Anahtar Sözcükler: Standardizasyon, Hizmetler, Vatandaş Sözleşmeleri.

JEL Classification: F53, O19.

\footnotetext{
*Turkish Standards Institution, Standards Preparation Centre, Standardization Expert, fmalgan@tse.org.tr
} 


\section{INTRODUCTION}

Standardization is an important tool for achieving economic growth, expansion of business markets and development of new sectors. Standardization provides economic benefits such as decreasing costs, using economies of scale and increasing market share as well as socioeconomic advantages such as increasing employment and labor capacity efficiency.

Standards provide support on development of negotiation culture in the relevant sector as the nature of such documents consists of a high level of participation and consensus. If the purpose for enterprises participating in standardization activities is to establish business partnerships and networks, participation of standard preparation activities will provide this opportunity to the enterprises and will enable them to obtain immediate results (de Vries, 2006, s. 136). Since enterprises may take the chance to learn and improve technical developments in connection with their products by the support of standards, their performance and economical intelligence increases (Cid, 2012). Standardization encourages information and R\&D activities. By participating in standard preparation activities, the enterprises may influence the standards and ensure that texts of standards are prepared in a way they require. Enterprises outside the standardization network, on the other hand, are obliged to comply with the standards that are determined by their competitors and produce according to the production conditions of the others (de Vries, 2006, s.136).

By standardization technical barriers to trade throughout Europe are eliminated and the standards contribute to an effective process in terms of the European Single Market. An effective process in terms of the European Single Market increases trade volumes of exporting enterprises (CEN-CENELEC-ETSI, 2010). Standards which contribute to the development of new sectors such as service sector ensure that the services provided throughout the Europe are compatible with an increased service quality.

This article introduces benefits of standards for industry, growth and SMEs and introduces standardization work of European Commission and European Standards Organisations on services and offers standardization of public services in the light of Citizen Charters.

\section{STANDARDS BOOSTING EUROPEAN COMPETITIVENESS}

\subsection{Benefits of Standards for Industry}

As participation in standard preparation means determination of production conditions, being in the standardization network provides advantages for competition in terms of enterprises (Toorn, 2012). Standardization provides many economical advantages from savings of time and cost to increasing market share and from eliminating technical barriers to preventing unexpected situations.

Standardization helps enterprises to enter into current markets and to determine market requirements. In addition, necessary changes can be made when new techniques and needs are brought 
up by standards. In this sense, standards are strategic tools for influencing the market (Cargill, 1989, ss. 41-42). Standards also support establishment of new markets as they provide help in development of products and services (CEN-CENELEC-ETSI, 2010). Preparation of standards in developing products and sectors such as petroleum products, IT products, organic products, both provides growth in the said sectors and develops their markets.

Nowadays, standards are significantly important instruments in the development of the global trade. Many enterprises that deal with international trade intend to participate in national and international standardization activities (IEC, a, 2012: 14-17). It is even a requirement for enterprises to participate in standardization network in order to gain international competition superiority and manufacture products compatible to these markets. Thus, the enterprises reach to a serious increase in their import and export volumes.

Standardization is an important tool that provides cost advantages to enterprises. The enterprises ensure cost saving by reflecting production conditions on the texts of the standards or resolving problems through standardization. A cost advantage would be provided for the companies when conditions to be set out in the standards, such as ensuring international compatibility and testing requirement, are determined by the companies. While standardization provides the opportunity for unity, solidarity and common terminology it also ensures to prevent unexpected situations.

As the standards reduce variable and fixed costs for producing one unit, they support the economies of scale. The costs for operation are not always economical. There are also costs for operation at negotiation stages. Standardization ensures to reduce the costs for operation arising from negotiation by mutual recognition. It is possible to prevent disputes by defining technical features of the products through standards. In the same way, standards ensure that costs for research are reduced as the time spent for evaluating products is reduced by standards. Reducing operational costs will make market more efficient (IEC, b, 2012: 8-11).

Enterprises get the opportunity to be informed earlier about the developments of standards and market when they participate standardization activities. Standards are the best instrument for identifying new products and technologies immediately at the earliest stage. Standardization ensures time savings and competition advantage for the enterprises by accelerating access to global markets (CEN-CENELEC-ETSI, 2010). The enterprises that participate in standardization activities learn new requirements and production techniques before the other enterprises in the market and they get the opportunity to apply the new conditions. While the other enterprises in the market seek to manufacture and offer new products, the enterprises in the standardization network will be placing the said products on the market. The abovementioned time advantage will provide competition superiority to the enterprises. 
Standard preparation activities create a network for many enterprises to get together (IEC, a, 2012: 18). During standard preparation activities, the enterprises are informed about production conditions of each other and get the opportunity to work together. Therefore, many enterprises that work in different processes of production and services find the opportunity to get to know each other and establish partnership. Thus, standardization brings many people and enterprises together and sets the stage for establishment of networks among the enterprises (Cid, 2012).

Standards assure that product quality increases and security requirements are met as they are prepared by the state of the art technologies (CEN-CENELEC-ETSI, 2010). Hence, the enterprises take the competition advantage in the market as they can offer safer products and services with higher quality. Implementation of Quality Management Systems such as Quality (EN ISO 9001) and Environment (EN ISO 14001) enables that the enterprises have a superior position in the market. Standards support environmental protection and development of sectors related to environment. In addition standards are the instruments which enterprises can use to comply with the EU Directives on Environment and Protection that are issued within the framework of the EU legislation.

\subsection{Benefits of Standards for Growth}

By standard implementation, gross domestic product in the EU has increased $1 \%$. Standards which increase national competitiveness also contribute to increase exports of the countries (DIN, 2000). Macroeconomic impact of standardization activities on national economies are more than individual contribution of each industrial sector (IEC, b, 2012: 5).

Nowadays, it is foreseen that global trade is supported by more than five hundred thousand standards (IEEE, 2012). According to data of OECD, $80 \%$ of global trade is directly influenced by standards. It is foreseen that impact volume of standards is more than 4 trillion \$ (OECD, 1999). Standards support increase in trade by contributing compatibility of products (IEC, b, 2012: 23). Standards guide foreign producers and consumers and positively affect investment decisions of foreign producers as they set off market conditions and make them transparent (DIN, 2000). In addition, standards enable enterprises to reach 500 million consumers (CEN-CENELEC-ETSI, 2010).

Standards are voluntary. Mostly laws do not mandate products of the producers to comply with standards. As a matter of a fact that customers require compatibility of standards as standards make life safer, healthier and easier. Standards that set for the compatibility of the products and services for safety, health and environment by international consensus ensures that quality of the products are comparable as the results that are obtained, when implemented by the same integrity in different places in the world, are comparable (IEC, a, 2012: 20). Thus, standards contribute to international compatibility.

Standards in the developing sectors such as service sector ensure that the sector develops more quickly and within the framework of requirements. Therefore, compatibility is provided and service 
quality is increased in terms of services provided throughout the European Union. Not only in service sector, but also in sectors where technological developments are important such as IT and telecommunication sectors, standards support development and business opportunities, and therefore employment by making definitions for work and labor capacity. For example, according to a research made in the United Kingdom, use of standards increased labor capacity efficiency by $13 \%$ between 1948 and 2002 (IEC, b, 2012: 5). A similar example can be given for agriculture sector. By increased use of organic products and standards in this regard, organic product market grew and therefore employment in this sector increased. According to data of CEN for the period of 2012, if organic product market keeps growing at the same rate, it will reach up to three times of the current market volume, i.e. 250 billion $€$. This will increase employment and volume increase will reach up to 380.000 people (Toorn, 2012).

Standards ensure product and service compatibility as well as interoperability (CENCENELEC-ETSI, 2010). Standards enable to use a common terminology such as units of measurement. For example, "m" is used for meter, "kg" is used for kilogram, and abbreviations and codes such as "A3" and "A4" is used for paper size all around the world (IEC, a, 2012: 7). This uniform terminology facilitates life, ensures global trade and increases safety.

As standards are the documents that declare compatibility in products, services and processes, they assure predictability and invariability. Therefore, the use of standards provides a predictable and stable environment to the enterprises. If different electric connections and plugs are used all around the world, there would be many difficulties for people travelling. The same difficulties would occur for computer keyboards and mobile phones. The compatibility provided by the standards is also crucially important for safety. The market becomes homogenous by national and international compatibility (Cid, 2012). This homogeneousness assures safety for the producers and consumers as well as ensuring market growth.

As R\&D studies provide data when standards are prepared, standardization supports $R \& D$ activities and encourages innovation. In this way, the results of R\&D studies are actively used in standard preparation stages and production processes and researches can be used effectively (CENCENELEC-ETSI, 2010). Participating in standardization activities ensures the enterprises to be informed about current and future technological conditions and know-how and provides the opportunity to access to wide strategic information (IEC, a, 2012: 17). Researchers and engineers use standards for being informed about the state of the art technologies (IEC, b, 2012: 6).

Standards prevent information asymmetry that can be encountered between the producer and the consumer. The text of the standards for which expectations of both parties are declared as joint consensus provides the opportunity for the producers to be informed about the expectations of their customers and to prevent probable market failures. The consumers, on the other hand, will be able to 
distinguish low quality products and high quality products and to make the right choice by implementation of standards (IEC, b, 2012: 10).

\subsection{Benefits of Standards for SMEs}

SMEs constitute $95 \%$ of the world's trade (ISO Focus, 2006). According to the data of 2006, 22 million SMEs undertake 75\% of the entire employment in Europe (Gourtsoyannis, 2006, s.41). Although SMEs have such a great economic importance, it is hard to say that they sufficiently participate in standardization activities. The ones who set out the standards dominate the market. In other words, the ones who contribute to development of the standards get the opportunity to access to the market in a much shorter time. The ones who do not participate in the said activities, on the other hand, are mostly forced into comply with the standards in a short time and cover high compatibility costs because of the pressure of their competitors. Standardization comprises one of the fundamental factors of success for all, ranging from a single company to the economy of the entire country. Participating in standardization activities and using standards will open the gate of quality management and increase competition capacity for SMEs.

SMEs need to participate in national, regional and international standardization network to comply with the world markets. This will provide many advantages to SMEs in various fields. It is possible to list the said advantages as in the followings:

- By participating at standard preparation activities, SMEs will be informed on product and production techniques stated in the standards and will be able to reflect their own production conditions on the standards;

- Therefore, they will gain information and time advantage as well as competition superiority;

- Operation costs shall be reduced as a result of cost savings for SMEs by standards supporting formation of economies of scale;

- Their know-how will increase, which will develop their products and services;

- Their commercial activities and market share will increase;

- Standards will increase product safety and reduce risks during production; SMEs producing high quality products will have competition superiority, increase customer satisfaction and trust, and strengthen market success;

- Standards will enable SMEs to manufacture products that comply with national and international legislation (especially CE Marking and EU New Approach Directives), ensure that products and services are compatible, and provide conformity assessment;

- Standardization activities support creation of a common sense in the market and serve as a base for product certification (attachment of quality mark on the product); 
- As standards will provide information on market share and potential, it will also ensure information on new entrepreneur opportunities and market access; participating in standardization activities in developing sectors such as services will provide SMEs to enter into new markets and competition superiority;

- As standards prevent unexpected situations, they will provide predictability and risk management follow up for SMEs;

- By participating in standardization activities, SMEs will have the advantage to contact with new enterprises and establish commercial relation and/ or partnerships;

- As standardization supports R\&D activities, it will facilitate access to R\&D data to which they cannot access with their current means;

- It will enable development and outspread of innovation;

- It will enable companies to increase their brand value and carry it to the international stage;

- Standards provide the opportunity to access to information and know-how;

- SMEs will have information flow on production and service provision through practical solutions offered by standards.

CEN and CENELEC carry out various activities for ensuring SMEs to participate actively in standardization processes. By workshops organized under the name of CEN and CENELEC Standard Days standardization activities and standard trainings are provided to SMEs, and on certain days of the week, SMEs are invited to visit CEN-CENELEC Management Center. On the said visiting days, SMEs are informed about standard preparation activities at CEN and CENELEC. Also SME consultancy services are provided by special tool that is allocated for SMEs on CEN website, and questions of SMEs are immediately answered when they contact with CEN. In addition, announcements in connection with benefits of SMEs by standardization, events organized for SMEs are made by CEN and CENELEC SME Help Desk. By issuing certain documents as regards to SMEs, CEN determines procedures concerning SME participation in standard preparation processes. By publishing Guide 17 - Guidance for writing standards taking into account micro, small and mediumsized enterprises (SMEs) needs, CEN and CENELEC ensures that needs and expectations of SMEs are taken into consideration in standardization activities and processes.

\section{EUROPEAN STANDARDS FOR SERVICES}

There are a lot of service types ranging from public transportation to telecommunication services. Providing safe access to these services influence life quality of humans. When long-term effects of the services such as environment, training and etc. are taken into consideration, the method of providing the said services becomes significantly important. Service sector is one of the developing sectors with 
high volume all around the world. Therefore, qualitatively important services have a key role in the economy as well as significant economic and social importance (CEN-CENELEC, 2012).

Service sector constitutes $20 \%$ of world trade and $2 / 3$ of global gross domestic product. In 2008 , share of service sector in gross domestic product was nearly $80 \%$ in the USA and more than $70 \%$ in the EU. In 2007, share of service sector in total employment was $70 \%$ in the EU and more than $70 \%$ in the USA (WTO, 2010). In 2010, in Turkey, share of service sector in gross domestic product was $72.4 \%$. In the same year, service sector constituted 55\% of total employment. In 2011, growth in service sector was $7.8 \%$ (WTO, 2012).

The EU puts efforts for effective operation of the European Single Market in terms of services in order to assure free movement of services, service provision freedom and offering high quality services. In the light of the importance of ties among the services, countries and people living in the EU for economic and social development, 2006/123/EC Directive on Services in the Internal Market is published and put into force. By this Directive it is aimed to reduce technical barriers in the service sector, to ensure compatibility of the services provided in the entire EU, to increase service quality, to enable service providers to offer services in any country where they wish to display activities, and to assure better services in return of less prices. Directive supports compatibility of services provided in different countries, information flow and increase in service quality. Technical barriers in the sector prevent service providers to benefit from the Single Market and to increase extraterritorial trade. This reduces competitiveness of the EU in the global market. The Single Market to be established for services will reduce limitations in extraterritorial trade and increase transparency and information flow for the consumers, and therefore it will increase options of the consumers and ensure them to purchase better services in return of less prices (2006/123/EC).

The importance of standardization for establishing and strengthening the Service Single Market is significant. Preparation and implementation of standards will encourage extraterritorial trade, improve safety and performance and ensure environmental protection. Service standards constitute 3\% of the entire European standards. Between 2005 and 2009, only 24 service standard was prepared. Throughout the Europe, many standard organizations prepare service standards in increasing numbers. The number of national service standards which were prepared in the same period is 453 . In 2005, CEN has made a feasibility study with regard to the service sector upon request of the EC. As the result of the CHESSS Study (CEN's Horizontal European Service Standardization Strategy), it is seen that many national service standards have been prepared in the Europe (complaint mechanisms, external resource use and etc.), but these standards do not generally meet market needs.

Technical barriers increase throughout the Europe because of preparation of so many different service standards in the national level. On the other hand some of these standards do not generally meet market needs. In order to systemize standardization of services provided in the EU, the EC issued 
and delivered a Mandate for the Programming and Development of Horizontal Service Standards numbered M/517 to the ESOs. Today, the Mandate is at the approval stage. The followings are aimed by this document:

- Enabling service market to grow;

- the Member states and the EU Commission's developing policies on service quality for;

- Developing standards in order to ensure compatibility and comparability of services provided in different countries by different methods.

It is expected to make an explicit plan to develop horizontal service standard, establishing voluntary service standards in line with market needs and increase service quality throughout the Europe by this Mandate published for ensuring compatibility in service and service standards, increasing service quality and meeting the requirements of 2006/123/EC throughout the Europe.

European standards are prepared to cover many fields of service. Great advantages are provided for industrialists and consumers by preparation of European service standards. The enterprises will use the standards for measuring and improving quality of the services they provide. Consumers will be able to determine which service provider gives higher quality services. The same determination will be made for pricing, and this will increase trust of the consumers. Public authorities are main service receivers. Standards play an important role in establishing basic information and determining basic requirements in connection with services received or provided by public authorities. CEN and CENELEC support Single Market for services and put efforts for raising awareness in advantages of standardization (CEN-CENELEC, 2012).

CEN and CENELEC provides to all stakeholders the opportunity to develop the related standards in connection with various products and services. CEN has published 85 standards and specifications in the field of services (by data at the end of 2011). These standards and specifications are prepared in the following fields:

- Airport and aviation security services

- Business support services

- Cleaning services

- Construction enterprises

- Customer contact centres

- Facility management

- Film identification

- Furniture removal

- Hearing aid professionals

- Language study tour providers

- Maintenance services

- Management consultancy services 
- Postal services

- Print media surveys

- Real estate agents

- Recreational diving

- Security service providers

- Self storage services

- Tourism services

- Transport services

CEN and CENELEC are developing new standards and specications in relation to a wide range of service areas. These include: aesthetic surgery, beauty salons, expertise services, fire safety and security systems, indoor sun exposure facilities, maritime and port security, pest management, sheltered housing for the elderly, and osteopathy among others (CEN-CENELEC, 2012).

CEN published the relevant EN 13816 - Transportation - Logistics and services - Public passenger transport - Service quality definition, targeting and measurement standard concerning public transportation services in 2002. It sets out common criteria for evaluating the quality of these services, covering a wide range of aspects such as accessibility, cleanliness, comfort, punctuality, and the provision of information to passengers. Standard provides; a framework for increasing quality throughout all operations, constant feedback allows identification of problems and corrective action and focus on customer satisfaction and a qualityoriented culture amongst staff (CEN-CENELEC, 2012). The other European standards such as EN 12522 Furniture removal activities, EN 15038 Translation services, EN 14153 and EN 14413 Recreational diving services standards regulate requirements in the relevant fields of services. As in EN 13816, publication of these service standards provides many advantages such as providing information flow, increasing service quality, following up performance, determining explicit activity procedures.

\section{AN OLD APPROACH AS A NEW PROPOSAL: STANDARDIZATION OF PUBLIC SERVICES}

In 1990s, various efforts were initiated for preventing communication gaps between administrations and citizens. To activate public administration and increase the quality of public services, governments implemented various approaches like governance (World Bank), good governance (EU), providing participation of citizens in public policy processes as stakeholders (OECD). Some of these efforts aim to accept citizens as "partner-stakeholder" and to include citizens in public policy processes (Coşkun, 2010, p. 89-90). As a result, governments started to make attempts for guaranteeing citizen rights and meeting requests and complaints under the titles like Citizen's Charter, Customer's Charter and Public Service's Charter. One of the most prominent aims of 
Citizen's Charters is to increase citizen trust by providing a transparent and accountable public service that is responsive to requests and expectations of the citizens.

Citizen's Charters were firstly put into effect in the United Kingdom in 1991 in the period of Prime Minister John Major as a ten years program. Citizen's Charters are defined as "a document to represent systematical efforts for the citizens/customers in the context of service standards of a public organization, information, complaint, courtesy, selection and consultancy, accessibility, nondiscrimination, esteeming public money". In other words, Citizen's Charters are agreements including the promise of the state, which constitutes a mechanism between the citizens and public organizations, by which a public organization declares citizen expectations, transparency of information and effective use of resources to public opinion, and thus improving quality and troubleshooting in public services. This charter includes information stating which services are to be provided how and when and who will be responsible for the service and complaint mechanisms in the case of noncompliance to the promised service standards. It is aimed to set out quality standards by charters, evaluate performance accordingly and improve the services based on information received from the citizens on current quality level. These charters set forth both quantitative (such as railway transportation expecting time) and qualitative (such as respect for private life of patients) standards. Citizens have the right to complain if the services do not have the promised standard. On the other hand, when the services provided have lower quality and quantity than the promised standard, it is possible to claim for pecuniary damages excluding some exceptions such as electricity, water and railway services (Coşkun, 2010, p.92).

In the UK, at the end of 1990s, national Citizen's Charters were prepared in main fields of services such as Patient's Charter, Parent's Charter, Court's Charter, Tax Payer's Charter and etc. These charters ensured that standards in connection with the services are determined, quality in public services is increased by award system, and citizens are involved in the services by stating their requests and complaints regarding the services. In many countries such as Germany, Australia, Belgium, Canada, France, India, Jamaica, Malaysia, Portugal, Spain, citizen charters are prepared and public services are standardized accordingly.

\subsection{Standardization of Citizen's Charters}

In the UK, citizen charters have especially been prepared in three fields as of the first years of the implementation. These fields are education, health and transportation. Parent's, Patient's and Railway Charters that are prepared in these fields are regularly revised and applied.

In the field of education, the first Parent's Charter was prepared in 1991. The purpose of the charter is to enlarge options of the families for schools of their children and to determine standards thereon. By implementation of Parent's Charter, five main documents are undertaken to be provided 
by educational institutions to the parents. These documents can be listed as in the followings (http://education.gov.uk/):

- a report on their child's progress at least once a year;

- regular reports on their child's school from independent inspectors;

- performance tables for local schools;

- a prospectus or brochure about individual schools; and

- an annual report from the school's governors.

In 1991, positive changes were observed in the education system after the charters are issued. The most essential development was enlargement of family rights. In 1994, Parent's Charter was updated and points such as what families would request from the education system and how their children could be a more effective partner were included in the Charter.

Patient's Charter in the field of health is implemented in the UK and North Ireland. In order to ensure that everyone receives health services that they need, General Practitioners system is widely implemented throughout the country. General Practitioner is responsible for carrying out consultancy, vaccine, examination and treatment, medicine-prescription procedures concerning health problems, and transfer procedures to other health institutions or social services. By Patient Charter, all services regarding General Practitioner and standards in connection with the rights to have a practitioner, to choose practitioner and for services in all processes starting from the first examination to the discharging procedures are determined. The Charter includes institutions that are responsible for following up health service standards in the UK and North Ireland as well as authorities to which patient suggestions and complaints are forwarded (http://www.adviceguide.org.uk/). The Charter also regulates various points such as informing patient and patient relatives, complaint mechanism, solution of problems and feedback mechanisms, treatment services for disabled people and supporting families. In the Charter, it is stated that patients can vote for performance of their practitioner if they require as well as working conditions and working hours of general practitioner. New General Practitioner Offices can be opened according to needs. By this implementation, it is aimed that the citizens can reach to practitioners whenever they require 365 days from 8:00 a.m. to 8:00 p.m. (http://www.nhs.uk/Pages/HomePage.aspx).

Railway Services has been another main fields stated in the Charter since Citizen's Charter implementation started in the UK. By Railway Charter, service standard regarding railway services are determined. In the Charter, the followings are stated: state's responsibility for providing railway service, pricing system to be implemented in the service, rights and responsibilities of service users, and suggestion and complaint mechanisms concerning the services. Main responsibilities of the state when providing the services, security and signalization, engineering services and announcement of 
changes, following up security of railways, inspecting train accidents, ensuring safety for trains and stations are determined for railway services (https://www.gov.uk/browse/driving). Subservices and conditions for providing these services for which the state is liable to provide in all abovementioned fields are also stated in the Charter.

Citizen's Charters are determined by public authorities and the Charters are open to public opinion. However, surveys show that citizens are not sufficiently informed about the charters. Although they know about the Citizen's Charters, but many people do not know which field the charters are implemented or how they will take the advantage of the implementation (Pollitt, 1994, p.13). Consequently, standards do not reach to the users. It also shows that standards are lack of participation of the users when the users are not informed about preparation of the standards. There aren't any procedures determined for informing the people about the system and obtaining opinions of the citizens. When the said deficiencies are taken into consideration, preparation of Citizen's Charters by the ESOs as a "public service standard" will ensure that these documents to be prepared by experts who know standardization terminology and opinions of all parties will be reflected on these documents. Preparation of public service standards will strengthen public enquiry process and ensure that all related parties are informed and more people will be informed about the standards. Standards will be developed with an understanding of quality management system and it will be possible to increase service quality and to determine performance criteria. Within the scope of Directive numbered 2006/23 and Mandate numbered M/517, compatibility of public services will be provided throughout the EU, and these standards will ensure the development of the Single Market for services.

While public services are standardized, it will be useful to determine general framework of public services, rules to be fulfilled in providing services, rights of service users, standards to be expected from public services (such as time and quality), sanctions that may be implemented in the case of noncompliance to standards and procedures to be applied in providing public services (http://www.worldbank.org/socialaccountability_sourcebook/ Tools/Other/cc.html). According to the Mandate numbered $\mathrm{M} / 517$, the definition of the service should be made by determining the followings:

- Definition of the service to be provided;

- Customer expectations;

- Situations with which the customers should not encounter;

- Where, when and how the service will be provided;

- Restrictions in providing services.

In addition, issues should be taken into consideration such as price, billing and payments, contact information, terms and conditions, customer communication channels, resolution methods, 
channels and response times, notification of changes to service, marketing and awareness, need for customer involvement.

EN 13816 has increased quality of transportation services, has ensured determination of problems and provided that measures are taken by means of feedback mechanisms and has aimed to provide customer satisfaction and development of internal quality culture. Standardization of public services in various fields such as telecommunication, education, health and etc. will ensure that citizen expectations are determined and service quality is increased. Assuring social accountability and usability of these standards will be useful for the society.

\section{CONCLUSION}

Standardization is an important tool for achieving economic growth, expansion of business markets and development of new sectors. Participating in standardization network provides economic and socioeconomic advantages for industry and SMEs.

Strengthening service sector which constitutes $20 \%$ of world trade and increasing its competitiveness will increase economic growth and business opportunities throughout the EU. Standardization of services will ensure service compatibility provided in the country, increase service quality and service providers to carry out activities in the entire Europe as well as supporting strength of the Single Market for services. In fact, European standards, which have already been prepared in the fields of public transport, furniture removal, translation and etc., increased service quality, constant feedback allows identification of problems and corrective action and encouraged customer satisfaction and development of qualityoriented culture. The EC and the ESOs aim to develop standards to cover other fields of services and to ensure effective operation of service Single Market. Efforts in this field continue in a planned way.

Citizen Charters that have been implemented in many countries since 1990's aim to increase service users' trust by providing a transparent and accountable public service that is responsive to requests and expectations of the citizens. Standardization of public services by Citizen's Charters ensures that expectations are reflected to the services and quality of public services increases. However, it is seen in practice that citizens are not sufficiently informed about this implementation. Standardization of public services in various fields such as telecommunication, education, health by ESOs will increase awareness, compatibility of public services and service quality and will support development of service market. 


\section{REFERENCES}

Cargill, Carl F., (1989) "Information Technology Standardization: Theory, Process, and Organizations", Bedford.

CEN-CENELEC (2012) "European Standards Boosting the Single Market for Services", European Standards Organizations, Brussels, Belgium.

CEN-CENELEC (2010) "Guide 17 - Guidance for writing standards taking into account micro, small and medium-sized enterprises (SMEs)", European Standards Organizations, Brussels, Belgium.

CEN-CENELEC-ETSI (2010) "Standards Supports Innovation and Growth", European Standards Organizations, Brussels, Belgium.

CID, Elena Santiago, (2012) "Setting the scene-European Standards Organisations Perspective and Policy”, JWG EaS Conference Presentation, Brussels, Belgium.

Çoşkun, Selim (2010) "Citizen Charters: Implementation of Different Countries and Overall Assessment”, Journal of Selçuk University Social Sciences Institution, No. 24, pp. 87-102.

de Vries, Henk J. de, (2006) "Standards for Business-How Companies Benefit from Participation in International Standards Setting", International Electrotechnical Commission (IEC), Geneva, Switzerland.

DIN (2000) "Economic Benefits of Standardization”, Deutsches Institut für Normung e.V., Berlin, Germany.

EC (2013) "M/517 - Mandate Addressed to CEN, CENELEC and ETSI For The Programming and Development of Horizontal Service Standards", European Commission, Brussels, Belgium.

European Parliament and European Council (2006) "2006/123/EC Directive on Services in the Internal Market”, European Parliament and European Council, Brussels, Belgium.

Gourtsoyannis, Loucas, (2006) “The Position of SMEs in International Standardization”, ISO Focus, Volume 3, No. 9.

IEEE (2012) "Benefits of standardization and standards", www.thinkstandards.net/benefits.html, (05.092012)

IEC (a, 2012) "Introduction to Standards", International Electrotechnical Commission, Geneva, Switzerland. 
IEC (b, 2012) "Economic Value of Standards", International Electrotechnical Commission, Geneva, Switzerland.

IEC (c, 2012) "The Strategic Value of International Standards", International Electrotechnical Commission, Geneva, Switzerland.

ISO Focus (2006). Standards : Big Benefits for Small Business, Volume 3, No. 9.

OECD (1999) Report on Regulatory Reform and International Standardization: Organisation for Economic Co-operation and Development, Paris, France.

Pollitt, Christopher (1994) "The Citizen's Charter: A Preliminary Analysis", Public Money \& Management, pp. 9-14.

Toorn, Sander van der, (2012) "Student Perspective on Education/Training About Standardisation in Europe", JWG EaS Conference Presentation, Brussels, Belgium.

WTO (2010) "Measuring Trade in Services-A training modüle", http://www.wto.org/english/res_e/statis_e/services_training_pres_e.pdf, (05.02.2013)

WTO (2012) "Trade Policy Review Report by the Secretariat Turkey, WT/TPR/S/259: World Trade Organisation, Geneva, Switzerland.

http://www.adviceguide.org.uk/ (Adviceguide-Citizens Advice), (05.04.2013)

http://education.gov.uk/ (Department for Education), (05.04.2013)

https://www.gov.uk/browse/driving (UK Government), (05.04.2013)

http://www.nhs.uk/Pages/HomePage.aspx (Healthcare), (05.04.2013)

http://www.worldbank.org/socialaccountability_sourcebook/Tools/Other/cc.html (Worldbank Social Development Department), (05.04.2013) 


\section{ANNEX A - ABBREVIATIONS AND ACRONYMS}

CEN

European Committee for Standardization

CENELEC European Committee for Electrotechnical Standardization

EC

European Commission

ESOs

European Standards Organisations

EU

European Union

IEC

International Electro-technical Commission

ISO

International Organization for Standardization

IT

Information Technologies

OECD

Organisation for Economic Co-operation and Development

$\mathrm{R} \& \mathrm{D}$

Research and Development

SMEs

Small and Medium-sized Enterprises

UK

United Kingdom

WTO

World Trade Oragnisation 